\title{
1 Bisaccate pollen from the Early Permian OSPZ3a Sub-Biozone of the \\ 2 Lower Gharif Member, Oman
}

3

4 Michael H. Stephenson *

5

6 British Geological Survey, Keyworth, Nottingham, NG12 5GG, UK

$7 \quad$ * Corresponding author. E-mail address: mhste@bgs.ac.uk.

8

9

10 Abstract

11

12 The OSPZ3a Sub-Biozone, associated with the lowest part of the Lower Gharif Member, is

13 part of biozonal scheme that was intended to unify the palynological schemes across Arabia.

14 This paper describes and illustrates the main bisaccate pollen taxa from the OSPZ3a Sub-

15 Biozone of the Well A cored well, Oman, between 2842.69 and $2852.82 \mathrm{~m}$, where they are unusually well preserved. Pteruchipollenites indarraensis which is the most common

17 bisaccate pollen taxon, reaching 40 to $50 \%$ of assemblages, is here placed in synonymy with

18 Alisporites tenuicorpus Balme, 1970, the latter being its junior synonym. Striatopodocarpites

19 cancellatus consistently first occurs in the OSPZ3a Sub-Biozone, and well-preserved

20 specimens are present in Well A, but Arabian specimens appear to have a wider range of

21 morphology, mainly in the arrangement of taeniae, than the type material. The relationship of

22 the genus Striatopodocarpites to Verticipollenites Bharadwaj, 1962, Lahirites Bharadwaj,

231962 and Hindipollenites Bharadwaj, 1962 is also examined with the result that

24 Striatopodocarpites is asserted as the senior synonym. The taeniate bisaccate pollen

25 Hamiapollenites fusiformis Marques-Toigo, 1974 is unusually common in the Well A 
assemblages and its morphology is found to be distinct from the similar multi-taeniate bisaccate taxon Striatoabieites multistriatus (Balme and Hennelly) Hart, 1964, with which it is sometimes placed in synonymy.

\section{Key words:}

\section{Introduction}

The Gharif Formation (the upper formation of the Haushi Group, Hughes Clarke, 1988) overlies the Al Khlata Formation both disconformably and conformably and is in turn overlain conformably by the marine carbonates and marginal marine to non-marine 'red-bed' clastics of the Khuff Formation (Osterloff et al., 2004). The formation is subdivided into 3 members: the Lower, Middle and Upper Gharif members, using subsurface sections (Forbes et al., 2010; Fig. 1). In South Oman, the lower part of the Lower Gharif Member is a complex of fluvial and fluviodeltaic clastics succeeded by marginal marine clastics toward the top; while in North Oman similar lower clastics give way to bioclastic limestone, known locally as the Haushi limestone (Fig. 1). The surface equivalent of the Lower Gharif Member was termed the Saiwan Formation by the Bureau de Recherches Géologiques et Minières (BRGM) (Dubreuilh et al., 1992; Platel et al., 1992; Roger et al., 1992). The Middle Gharif Member is a sequence of marginal marine clastics overlain by lacustrine and fluvial units, capped by stacked palaeosols (the ‘Playa Shale’ sensu Guit et al., 1995), deposited in a semiarid climate. Lying unconformably above the Middle Gharif Member is the Upper Gharif Member. The upper part of this clastic unit contains abundant plant remains (Broutin et al., 1995) in the outcrops of the Northern Huqf area. 
52 Age determinations for the Lower Gharif member rely mainly on macropaleontological dates

53 from the Haushi Limestone. Miller and Furnish (1957) and Hudson and Sudbury (1959)

54 suggested Mid Permian and Sakmarian-Artinskian ages respectively for fauna from the

55 Haushi limestone. More recent foraminiferal evidence (Angiolini et al., 2006) suggests a

56 Sakmarian age for the Haushi limestone, providing an upper age limit for the Lower Gharif

57 Member.

58

59

60

\section{OSPZ3a}

61

62 The OSPZ3a Sub-Biozone, is part of biozonal scheme that was intended to unify the

63 palynological schemes across Arabia (Stephenson et al., 2003). The OSPZ3a Sub-Biozone is

64 succeeded by the OSPZ3b and OSPZ3c sub-biozones. Compared with the other biozones of

65 the OSPZ scheme, the three sub-biozones are smaller in scale and somewhat localised in

66 geographical extent, and appear not to be recognisable throughout Arabia either due to

67 palaeophytogeographical variation or hiatus.

68

69 The base of OSPZ3a Sub-Biozone is marked by the most distinct palynological discontinuity 70 in the Lower Permian section, which corresponds closely to the transition between the Rahab

71 Shale Bed of the Al Khlata Formation and the Lower Gharif Member, and may also be linked

72 with post-glacial climatic change (Stephenson and Osterloff, 2002; Stephenson et al., 2005).

73 The base is defined by the abrupt increase of the small non-taeniate bisaccate pollen

74 Pteruchipollenites indarraensis from approximately 10 to 50 or $60 \%$ of assemblages. This

75 increase is accompanied by an increase in coarsely ornamented forms of Cristatisporites (to a 
maximum of approximately $4 \%$ of assemblages). Other taxa that occur first consistently in OSPZ3a Sub-Biozone are the taeniate bisaccate pollen Striatopodocarpites cancellatus and S. fusus, and the taeniate 'circumstriate' pollen taxa such as Circumstriatites talchirensis and

Striasulcites tectus. The colpate pollen Kingiacolpites subcircularis is common throughout, occasionally reaching $50 \%$ of assemblages, but more typically $5-10 \%$ of assemblages. The base of OSPZ3b Sub-Biozone is defined by the first uphole appearance of the algal cyst Ulanisphaeridium omanensis Stephenson and Osterloff, 2002.

\section{3}

It is difficult to generalise about the relationship between the 2141C Biozone of Penney et al. (2008) and OSPZ3a, and there may be some overlap in character. However 2141C contains more common Cycadopites cymbatus, and coarsely ornamented triangular fern spores such as Converrucosiporites grandegranulatus and Converrucosiporites sp. A of Stephenson and Osterloff (2002) (see also Stephenson, 2004). 2141C is regarded as an approximate equivalent of the Converrucosiporites sp. A - Microbaculispora grandegranulata Biozone of Stephenson and Osterloff (2002).

This paper describes the main bisaccate pollen taxa from the OSPZ3a Sub-Biozone of the Well A cored well (Fig. 2) between 2842.69 and 2852.82 m (driller's depths) within the Lower Gharif Member. Well A assemblages represent a typical post-glacial Lower Gharif Member flora. The simple bisaccate pollen may have been produced by upland plants, while the lowland may have been populated by colpate pollen-producing cycad-like plants (Stephenson and Osterloff, 2002; Stephenson et al., 2005). Spores of the Lower Permian succession have been described previously (Stephenson, 2004), but pollen have not, mainly because preservation is generally poor amongst the bisaccate pollen of the Lower Gharif Member. However the core of Well A yielded relatively well-preserved bisaccate pollen from 
101 the OSPZ3a Sub-Biozone, allowing this part of the palynological succession in Oman to be 102 described and illustrated.

103

104

105

3. Materials and methods

106

107 Preparation of strew mounts for palynological analysis involved well-established procedures

108 of crushing followed by hydrochloric and hydrofluoric acid treatments (Wood et al., 1996).

109 Post-hydrofluoric acid organic residues were oxidised with Schulze’s Solution and dilute

110 nitric acid. Slides are held in the collection of the British Geological Survey, Keyworth,

111 Nottingham, NG12 5GG.

112

113 The terminology used is that of Punt et al. (1994) and Smith and Butterworth (1967).

114 Maximum equatorial dimensions are given in microns $(\mu \mathrm{m})$; and the scheme of dimensions as

115 given in Fig 3. Previous records of taxa given here are not meant to be exhaustive, but to

116 focus on Middle Eastern occurrences. Stratigraphical ages for these occurrences are those

117 suggested by the respective authors.

\section{Systematic palynology}

121

122 Genus Pteruchipollenites Couper, 1958

123

124 Type species: Pteruchipollenites thomasii Couper, 1958. 
Pteruchipollenites indarraensis (Segroves) Foster, 1979 (Plate I, 1-18)

127

1970 Alisporites tenuicorpus Balme; p. 394; pl. 15, figs. 1-4.

1988 Pteruchipollenites sp. 1 MacRae; p. 56-57; pl. 22, figs. 7-8, 11-13, 15-16, 18-19.

130

131 Description: Pollen bilaterally symmetrical, bisaccate, alete; amb haploxylonoid oval to slightly irregular due to flaccid sacci. Corpus latitudinally oval, circular or rarely longitudinally oval; intexine thin $(<0.5 \mu \mathrm{m})$; exoexine over corpus intexine infrareticulate.

134 Cappula usually indistinct; when distinct, oval; margins sometimes imperceptible due to the

135 similarity of corpus and saccus exine. Saccus inclination distal; proximal saccus detachment 136 equatorial; distal saccus detachment 5-8 $\mu \mathrm{m}$ in from the distal outer margin of the corpus.

137 Sacci variable in size, usually with width $30 \%$ of the corpus width; crescentic in outline;

138 flaccid; infrareticulation fine (brochi size less than $1 \mu \mathrm{m}$ in diameter).

139 Mean dimensions: (37 specimens): corpus width $36.8 \mu \mathrm{m}$; total length $34.26 \mu \mathrm{m}$; maximum

140 offlap $7.05 \mu \mathrm{m}$; maximum onlap $10.06 \mu \mathrm{m}$; total width $51.11 \mu \mathrm{m}$.

141 Remarks: The rapid uphole increase in the abundance of $P$. indarraensis is not recorded in the 142 cored section of Well A and thus the base of the OSPZ3a Sub-Biozone is not present, but 143 Figure 4 serves to indicate its abundance. Figure 5 shows the base of the OSPZ3a Sub-

144 Biozone across the Rahab-2, Thuleilat-42 and 16, and Marmul-151 wells (data from

145 Stephenson and Osterloff, 2002). Due to its delicacy, it is often poorly preserved. The

146 preservation is poorer in the upper part of the Well A core, between 2842.69 and $2852.82 \mathrm{~m}$

147 (Fig. 4), with the result that many likely specimens of $P$. indarraensis were recorded as 148 'bisaccate pollen indeterminate' (Fig. 4). Poorly preserved specimens of $P$. indarraensis 149 usually occur as detached sacci or corpi. 
150 Pteruchipollenites indarraensis is similar to Alisporites tenuicorpus Balme, 1970, as noted by

151 Foster (1979). Alisporites tenuicorpus is diagnosed as having minor distal saccus inclination

152 and an oval cappula of width about half that of the corpus. $P$. indarraensis is diagnosed as

153 having a parallel-sided cappula of width 1/5-2/3 the width of the corpus. Segroves'

154 description of the cappula as parallel-sided is inconsistent, however, with the cappulae

155 figured (Segroves 1969; pl. 6, figs. A-E), which are oval in outline.

156 A careful study of a large number of the present specimens has shown that the distally-

157 inclined, flaccid sacci are compressed variably; sometimes inward toward the cappula,

158 sometimes outward to expose the cappula. When the sacci are pushed inward, folding

159 obscures the distal saccus roots and the cappula may appear to be narrow. When the sacci are

160 pushed outward by compression the cappula is exposed and stretched sideways so that it may

161 appear artificially wide. Furthermore, the similarity of saccus and corpus exine often makes

162 the determination of saccus onlap and cappula shape difficult to discern.

163 In view of the fact that $P$. indarraensis and $A$. tenuicorpus are separated on minor size

164 difference and cappula width (which may be influenced by preservation), it is suggested that

165 the two species be placed in synonymy with $P$. indarraensis as the senior synonym.

166 Pteruchipollenites sp. 1 MacRae, 1988 is also synonymous with $P$. indarraensis.

167 Previous records: Iran, Permian (Chateauneuf and Stampfli, 1979); Africa, Permian

168 (MacRae, 1988); Pakistan, Permian (Balme, 1970); Australia, Permian (Foster, 1979;

169 Segroves, 1969); Middle East, Permian (Stephenson and Osterloff, 2002; Stephenson et al., $1702003,2005)$.

171

172 Genus Hamiapollenites Wilson emend. Tshudy and Kosanke, 1966

173

174 Type species: Hamiapollenites saccatus Wilson, 1962. 
176 Hamiapollenites fusiformis Marques-Toigo emend. Archangelsky and Gamerro, 1979 (Plate

177 II, 1-10)

178

179 Description: Pollen bilaterally symmetrical, bisaccate, monolete, dilete or trilete, taeniate;

180 amb oval or diploxylonoid with very small sacci. Corpus oval, dark in colour; intexine thin,

181 punctate. Cappa has approximately 9 taeniae of dense, dark-coloured exoexine separated by narrow $(0.5 \mu \mathrm{m}$ wide) clefts which are floored by intexine. Taeniae parallel. Central striation deepened in the polar part of the cappa to form distinct monolete, dilete or rarely trilete mark.

184 Sacci small (width $<20 \%$ of the width of the corpus); situated at the latitudinal extremities of

185 the corpus only; sacci distally inclined. Occasionally thin unexpanded exoexine occurs at the margin of the corpus in the longitudinal positions; unexpanded exoexine 1-3 $\mu$ m thick. Distal exine of the corpus ?laevigate, usually with 2 indistinct longitudinal folds or ?thickenings;

thickenings masked by the thick cappa.

Mean dimensions: (7 specimens): total length $35.57 \mu \mathrm{m}$; maximum offlap $5.57 \mu \mathrm{m}$; saccus

190 length $10.71 \mu \mathrm{m}$; total width $46.14 \mu \mathrm{m}$.

191 Remarks: Marques-Toigo (1974) did not refer to haptotypic features in her diagnosis, but the figured holotype and a paratype (Marques-Toigo 1974; pl. 3, fig. 9 (holotype), fig. 7

193 (paratype) clearly have a monolete mark.

194 The present species is very similar to Hamiapollenites karrooensis (Hart, 1963) Hart, 1964.

195 The latter species differs, however, in having a smaller number of wider proximal taeniae and 196 in lacking a haptotypic mark (see Stephenson, 2008). H. bullaeformis differs from the present 197 species in having a single distal, longitudinal keel-like thickening (see Samoilovich, 1953).

198 Foster and Waterhouse (1988) tentatively considered Hamiapollenites fusiformis to be 199 synonymous with Striatoabieites multistriatus (Balme and Hennelly) Hart, 1964. Marques- 
200 Toigo (1974) did not compare her species with S. multistriatus. Via the respective diagnosis 201 and description (Marques-Toigo, 1974, p. 611; Balme and Hennelly, 1955, p. 93)

202 comparisons are difficult to make. A visual comparison of the respective figured specimens 203 (Marques-Toigo, 1974; pl. 3, figs. 7-10 (holotype fig. 9): Balme and Hennelly, 1955; pl. 2, 204 figs. 16-20 (lectotype fig. 17, designated by Hart (1964) however, show that the corpus of $S$. 205 multistriatus bears a larger number of narrower taeniae (approximately 20 taeniae in each of 206 the 5 figured specimens) than does that of $H$. fusiformis. Balme and Hennelly (1955) did not 207 specify the number of taeniae in their 'description', but Hart (1964) in his later 'diagnosis' 208 specified 12-16 taeniae. Marques-Toigo (1974) diagnosed 9-12 taeniae for H. fusiformis. 209 In addition, the figures appear to indicate that $H$. fusiformis has a generally darker and more 210 clearly oval corpus than S. multistriatus, and bears longitudinal distal thickenings which are 211 absent in S. multistriatus. Hamiapollenites fusiformis bears a haptotypic mark (usually 212 monolete) which appears to be absent in the figured specimens of $S$. multistriatus. 213 Previous records: Uruguay, Early Permian (Marques-Toigo, 1974); Argentina, Permo 214 Carboniferous (Vergel, 1987; Archangelsky and Gamerro, 1979, Césari et al., 1995); Middle 215 East, Permian (Stephenson and Osterloff, 2002).

216

217 Genus Striatopodocarpites Sedova emend. Hart, 1964 218

Type species: Striatopodocarpites tojmensis Sedova, 1956.

220

2211962 Verticipollenites Bharadwaj: p. 90-91; pl. 9, figs. 126-127, 129-136; pl. 10, figs. 137139, 143-146; pl. 11, figs. 158-159; pl. 12, figs. 160, 162-165, 168-171, 173; pl. 13, figs. $177-$ 223 178, 180, 186.

2241962 Hindipollenites Bharadwaj: p. 92-93; pl. 10, figs. 141-142. 
1962 Lahirites Bharadwaj: p. 91-92; pl. 11, figs. 152-153; pl. 12, fig. 172; pl. 13, figs. 181, 183, 188.

Remarks: The present author concurs with Hart (1964) in placing Verticipollenites Bharadwaj 1962, Lahirites Bharadwaj, 1962 and Hindipollenites Bharadwaj, 1962 in synonymy with the present genus. Hart (1964) did not give reasons for his synonymisation. An attempt will be made here to justify synonymisation.

Bharadwaj (1962) did not compare Verticipollenites with Striatopodocarpites but his comparison with other diploxylonoid taeniate pollen indicates that he believed

Verticipollenites to be distinct because of the outline of the saccus which is 'pitcher' or flaskshaped (see Bharadwaj, 1962, text-fig. 9). The figure of the holotype of the type species, $V$. secretus (Bharadwaj, 1962; pl. 12, fig. 160), does not clearly show this feature and the sacci outlines in other figured specimens are similarly obscure. In the absence of definite evidence to suggest that saccate arrangement in Verticipollenites is distinct, the latter genus, which has no other distinguishing features, is considered a junior synonym of the present genus.

240 Bharadwaj (1962) asserted that Hindipollenites is distinct from Verticipollenites only in its 241 intrapuncate ?corpus exine because it also has 'pitcher' or flask-shaped sacci. Generic differentiation based solely on minor corpus exine- taeniae exine differences is considered

243 unsafe because these may be of secondary origin. As in the figured specimens of

244 Verticipollenites, the figured specimens of Hindipollenites (Bharadwaj, 1962; pl. 10, figs.

245 141-142) do not clearly show "pitcher" or flask-shaped sacci and so Hindipollenites is 246 similarly considered to be a junior synonym of Striatopodocarpites. Lahirites purportedly 247 differs from Striatopodocarpites in lacking the latter's structured corpus exine. As has been 248 suggested above, the present author considers such differences as possibly secondary in 249 origin and for this reason considers Lahirites to be synonymous with Striatopodocarpites. 
251 Striatopodocarpites cancellatus (Balme and Hennelly) Hart, 1964 (Plate III, 1-8; Plate IV, $252 \quad 1-3)$

253

254 Description: Pollen, bisaccate, bilaterally symmetrical taeniate; amb diploxylonoid. Corpus 255 distinct, circular, dark in colour; cappa 1-2 $\mu$ m thick, distinctly taeniate. Cappula distinct, 256 narrow (20\% of the corpus width), parallel sided; delineated by narrow distal intexinal folds.

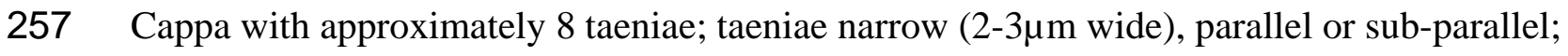
extend the width of the corpus; striations between $<1 \mu \mathrm{m}$ wide. Proximal saccus detachment equatorial; distal saccus detachment close to distal pole; sacci distally inclined. Sacci outline 260 is semi circular; sacci coarsely infrareticulate (brochi 1-2 $\mu$ m wide); sacci flaccid. Mean dimensions (5 specimens): total width $40 \mu \mathrm{m}$, total length $23 \mu \mathrm{m}$, corpus width $16 \mu \mathrm{m}$, saccus offlap $12 \mu \mathrm{m}$, saccus onlap $7 \mu \mathrm{m}$, cappula width $4 \mu \mathrm{m}$.

Remarks: Striatopodocarpites cancellatus is the most common diploxylonoid multitaeniate

264 bisaccate pollen occurring in OSPZ3a. Though most specimens fit well within the concept of 265 the species as described by, for example, Balme and Hennelly (1955) and Foster (1979), 266 some vary from that concept in two ways: in the form of taeniae, and in the development of rudimentary haptotypic marks. Although this is not discussed by Balme and Hennelly (1955) and Foster (1979) and other authors, Australian specimens of S. cancellatus tend to show rather regular, parallel taeniae. In a small proportion of Oman specimens, and also in Saudi

270 Arabian and Yemeni specimens, the taeniae are discontinuous or only sub-parallel. Some 271 Pakistan specimens of S. cancellatus from the Salt Range also show non-parallel taeniae (see 272 Balme, 1970). There is a continuum between such specimens and those with regular, parallel 273 taeniae, and thus it was not thought judicious to separate the two groups taxonomically.

274 Arabian specimens of $S$. cancellatus also sometimes bear a disruption of the taeniae in the 
275 central part of the cappa, suggesting a rudimentary haptotypic mark, usually a monolete or

276 dilete mark. Again such structures are not shown in illustrations of Australian specimens of $S$.

277 cancellatus, nor are they mentioned in descriptions. In cases where monolete marks are clear

278 (e.g. Plate IV , 4-5), such specimens are assigned to Strotersporites (see below).

279 Previous records: Israel, Late Permian (Eshet, 1990); Saudi Arabia, Late Permian (Hemer, 280 1965); Iran, Late Permian (Chateauneuf and Stampfli, 1979, Ghavidel-syooki, 1997); Oman, 281 Permian (Love, 1994; Broutin et al., 1995). Middle East, Permian (Stephenson and Osterloff, 282 2002; Stephenson et al., 2003).

283

284

285 Genus Strotersporites Wilson emend. Klaus, 1963

286

287

Type species: Strotersporites communis Wilson, 1962.

288

289 Remarks: Klaus' (1963) emendation of Strotersporites Wilson created a useful category for 290 monolete/dilete, taeniate, bisaccate grains otherwise similar to Striatopodocarpites Sedova 291 emend. Hart, 1964.

292

293 Strotersporites indicus Tiwari, 1965 (Plate IV, 4-5)

294

295 Description: Pollen bilaterally symmetrical, bisaccate, monolete or dilete, taeniate; amb 296 latitudinally elongate haploxylonoid. Corpus oval or barrel-shaped. Longitudinal margins of 297 the corpus often flat and concordant with the longitudinal extremities of the sacci so that the 298 grain overall has flat parallel longitudinal extremities. Intexine relatively thick $<1 \mu \mathrm{m}$; 299 expanded infrareticulate exoexine occurs on the taeniae and in irregular patches on the 
corpus. Cappula distinct, parallel-sided or rarely fusiform; bounded by two distal intexinal

301 folds marking distal saccus detachment zones. Intexinal folds lunate in shape $\sim 10 \mu \mathrm{m}$ wide in

302 the central part of the corpus. Width of cappula about $40 \%$ of the corpus width. 7- 11

303 proximal taeniae occur, 3-7 $\mu$ m wide, separated by narrow (1-2 $\mu$ m wide) striations.

304 Longitudinal extremities of corpus have narrower, convergent taeniae. Proximal saccus

305 detachment equatorial; distal saccus detachment close to distal pole. Sacci distally inclined;

306 outline greater than semi circular; robust, joined at the longitudinal extremities of the corpus

307 by thin strips of expanded exoexine. Saccus infrareticulation coarse (brochi 1-2 $\mu$ m, elongate,

308 radially arranged on distal side close to the corpus edge). Monolete mark large, distinct,

309 straight or geniculate; situated between the central two taeniae; length $50-80 \%$ of the corpus

310 width; intexine of corpus visible along the commissures. Rarely a dilete mark or

311 asymmetrical trilete mark is present.

312 Mean dimensions: (14 specimens): corpus width $44.78 \mu \mathrm{m}$; total length $51.64 \mu \mathrm{m}$; maximum

313 offlap $17.36 \mu \mathrm{m}$; maximum onlap $16.64 \mu \mathrm{m}$; total width $78.36 \mu \mathrm{m}$.

314 Remarks: The present specimens show a wider range of variation than that permitted by

315 Tiwari (1965). Tiwari allows 4-8 striations (=5-9 taeniae) whereas the present specimens

316 have between 7 and 11 (mean 8) taeniae. The specimens of Tiwari (1965) are also

317 considerably larger. These differences however are not considered to justify further

318 separation.

319 Rare specimens have a large dilete or asymmetrical trilete mark which is similar to the "type

320 3" branching striation described by Jizba (1962) in specimens of Complexisporites

321 polymorphus Jizba, 1962. The mark in the present specimens, however, is never associated

322 with a circumpolar striation as in the latter species. Small specimens of the present species

323 with poorly preserved corpi are however difficult to distinguish from C. polymorphus. 
324 Previous records: Libya, Ghzelian-Early Asselian (Loboziak and Clayton, 1988); India,

325 Early Permian (Tiwari, 1965); Middle East, Permian (Stephenson and Osterloff, 2002).

326

327 Genus Protohaploxypinus Samoilovich emend. Morbey, 1975

328

329 Type species: Protohaploxypinus latissimus (Luber and Valts) Samoilovich 1953.

3301962 Faunipollenites Bharadwaj: p. 95, text-fig. 12; pl. 17, figs. 220-228; pl. 18, figs. 229-

331234.

332

333 Remarks: Bharadwaj (1962) erected Faunipollenites to include taeniate, haploxylonoid pollen

334 grains similar to Protohaploxypinus but with an ill-defined corpus and infrareticulate cappa.

335 As defined, therefore, it appears to be similar to the type species of Protohaploxypinus

336 Samoilovich 1953 (see Luber and Valts, 1941; pl. 13, fig. 221) and Samoilovich (1953; pl. 4,

337 fig. 4) and presumably on this basis was rejected by Hart (1964).

338 Species of Protohaploxypinus in OSPZ3a consistently have thin, poorly defined corpi that

339 make them very distinct from the diploxylonoid bisaccate pollen such as Striatopodocarpites

340 which have smaller, darker, more distinct corpi.

341

342 Protohaploxypinus amplus (Balme and Hennelly) Hart, 1964 (Plate IV, 8)

343

344 Description: Pollen bilaterally symmetrical, bisaccate, alete, taeniate; amb oval to sub-

345 rectangular, haploxylonoid. Corpus slightly elongate oval or circular; intexine thin. Cappa

346 exoexine partly expanded, infrareticulate on the taeniae. Cappula parallel-sided to boat

347 shaped, width about $50 \%$ of the corpus; delineated by a pair of distal intexinal folds.

348 Approximately 8-10 latitudinal proximal taeniae occur; taeniae exoexine infrareticulate. Sacci 
distally inclined; proximal saccus detachment equatorial; distal saccus detachment close to distal pole. Sacci hemispherical in outline; appear to join adjacent to the longitudinal extremities of the corpus. Sacci robust; infrareticulation coarse, brochi $1-2 \mu \mathrm{m}$ in diameter. Mean dimensions: (8 specimens): corpus width $72.25 \mu \mathrm{m}$; corpus length $72 \mu \mathrm{m}$; maximum offlap $22.37 \mu$ m; maximum onlap $24.87 \mu$ m; total width $109.25 \mu \mathrm{m}$.

Remarks: Protohaploxypinus limpidus (Balme and Hennelly) Balme and Playford, 1967 was considered by Balme and Hennelly (1955) to be distinct from P. amplus because of its smaller size and thinner, finely granulate body exine. Later workers (e.g. Powis, 1979; unpublished $\mathrm{PhD}$ thesis) have shown that the latter also has a larger number of taeniae. Previous records: Iran, Permian (Ghavidel-syooki, 1997; Chateauneuf and Stampfli, 1979);

Libya, Ghzelian-Artinskian (Brugman et al., 1985 (as Striatoabietites amplus sic); Gondwana, Permian (e.g. Balme and Hennelly, 1955; Bose and Kar, 1966; Balme and

Stephenson and Osterloff, 2002).

Protohaploxypinus limpidus (Balme and Hennelly) Balme and Playford, 1967 (Plate IV, 9)

365

Description: Pollen bilaterally symmetrical, bisaccate, taeniate, alete; amb oval haploxylonoid. Corpus latitudinally oval; intexine thin; taeniae exoexine partially

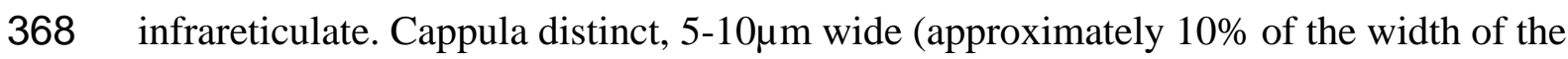
369 corpus); parallel-sided, extends the length of the corpus. Cappa with 5-8 taeniae; usually 370 convergent, 3-14 $\mu \mathrm{m}$ in width. Sacci strongly distally inclined with very narrow sacci 371 connections at the longitudinal margins of the corpus. Sacci detached equatorially on 372 proximal side of corpus, cappula margins mark the distal saccus detachment; saccus offlap 373 dimension usually approximately equal to saccus onlap dimension. Sacci semicircular in 
374 outline, roughly the same size as the corpus; infrareticulation fine to coarse $(0.5-2 \mu \mathrm{m}$ brochi 375 diameter).

376 Mean dimensions: (12 specimens): total width $69.33 \mu \mathrm{m}$; saccus offlap $14.83 \mu \mathrm{m}$; saccus 377 onlap $14.42 \mu \mathrm{m}$; corpus width $43.67 \mu \mathrm{m}$; corpus length $50.83 \mu \mathrm{m}$; total length $51.67 \mu \mathrm{m}$. 378 Previous records: Iran, Permian (Ghavidel-syooki, 1997, Chateauneuf and Stampfli, 1979); 379 Gondwana (e.g. Powis, 1979, Lindström, 1996, Backhouse, 1991; Stephenson and Osterloff, 380 2002; Stephenson et al., 2003).

381

382

383 Acknowledgements

384

385 The author is grateful to the Ministry of Oil and Gas and Petroleum Development, Oman for 386 permission to publish this paper. The author acknowledges constructive reviews by Stewart

G. Molyneux, James B. Riding and Gordon Forbes. Michael H. Stephenson publishes with 388 the permission of the Executive Director, British Geological Survey (NERC).

\section{References}

393 Angiolini, L., M.H. Stephenson and E.J. Leven 2006. Correlation of the Lower Permian surface Saiwan Formation and subsurface Haushi limestone, Central Oman. GeoArabia, v. 11, no. 3, p. 17-38.

Archangelsky, S. and J.C. Gamerro 1979. Palinología del Palaeozoico Superior en el 
de los palinomorfos de tres perforaciones de la Provincia de Córdoba. Revista Española de Micropaleontología, v. 11, p. 417-478.

400

Backhouse, J. 1991. Permian palynostratigraphy of the Collie Basin, western Australia.

401 Review of Palaeobotany and Palynology, v. 67, p. 237-314.

402

Balme, B.E. 1970. Palynology of Permian and Triassic strata in the Salt Range and Surghar

403 Range, west Pakistan. In, B. Kummel and C. Teichert (Eds.), Stratigraphic Boundary Problems: Permian and Triassic of West Pakistan. University Press of Kansas, Department of Geology Special Publication 4, p. 306-453.

406

407

408

409

410

411

412

413

414

415

416

417

418

419

420

421

Balme, B.E. and G. Playford 1967. Late Permian plant microfossils from the Prince Charles Mountains Antarctica. Revue de Micropaléontolgie, v. 10, p. 179-192.

Balme, B.E. and J.P. Hennelly 1955. Bisaccate sporomorphs from Australian Permian coals. Australian Journal of Botany, v. 3, p. 89-98.

Bharadwaj, D.C. 1962. The miospore genera in the coals of the Raniganj Stage, Upper Permian, India. Palaeobotanist, v. 9, p. 68-106.

Bose, M.N. and R.K Kar 1966. Palaeozoic sporae dispersae from Zaire (Congo) I. Kindu\Kalima and Walikale regions. Annales Musee Royal de L'Afrique Centrale, Sér. 8vo, v. 53, p. 1-168.

Broutin, J., J. Roger, J.-P. Platel, L. Angiolini, A. Baud, H. Bucher, J. Marcoux and H. Al Hasmi 1995. The Permian Pangea. Phytogeographic implications of new palaeontological discoveries in Oman (Arabian Peninsula). Compte Rendus de l'Academie des Sciences de Paris, Series IIa, v. 321, p. 1069-1086.

Brugman, W.A., J.W. Eggink, S. Loboziak and H. Visscher 1985. Late Carboniferous - Early Permian (Ghzelian - Artinskian ) palynomorphs. Journal of Micropalaeontology, v. 4, p. 93-106. 
422

423

424

425

426

427

428

429

430

431

432

433

434

435

436

437

438

439

440

441

442

443

444

Césari, S., S. Archangelsky and L. de Seoane 1995. Palinología del Palaeozoico Superior de la perforación Las Mochas, Provincia de Santa Fe, Argentina. Ameghiniana, v. 32, p. 73-106.

Chateauneuf, J.J. and G. Stampfli 1979. Preliminary report on Permian palynology of Iran. IV International Palynological Conference, Lucknow, v. 2, p. 186-198.

Dubreuilh, J., J.-P. Platel, J. Le Métour, J. Roger, R. Wyns, F. Béchennec and A. Berthiaux 1992. Explanatory notes to the geologic map of the Khaluf Quadrangle, Sultanate of Oman. Geoscience map, scale 1:250,000, sheet NF 40-15. Ministry of Petroleum and Minerals, Directorate General of Minerals, Sultanate of Oman. 92 p.

Eshet, Y. 1990. Paleozoic-Mesozoic palynology of Israel, I. Palynological aspects of the Permo-Triassic succession in the subsurface. Geological Survey of Israel Bulletin 81, p. 1-20.

Forbes, G.A., H.S.M. Jansen and J. Schreurs 2010. Lexicon of Oman subsurface stratigraphy: Reference guide to the stratigraphy of Oman’s hydrocarbon basins. GeoArabia Special Publication 5, Gulf PetroLink, Bahrain, 371 p.

Foster, C.B. 1975. Permian plant microfossils from the Blair Athol Coal Measures, Central Queensland, Australia. Palaeontographica, Abteilung B, v. 154, p. 121-171.

Foster, C.B. 1979. Permian Plant Microfossils of the Blair Atholl Coal Measures, Baralaba Coal Measures and Basal Rewan Formation of Queensland. Geological Survey of Queensland Publication no. 372, 244 p.

Foster, C.B. and J. Waterhouse 1988. The Granulatisporites confluens Oppel Zone and Early Permian marine faunas from the Grant Formation on the Barbwire Terrace, Canning Basin, Australia. Australian Journal of Earth Sciences, v. 35, p. 135-157. 
445 Ghavidel-syooki, M. 1997. Palynostratigraphy and palaeogeography of Early Permian strata

446

447

448

449

450

451

452

453

454

455

456

457

458

459

460

461

462

463

464

465

466

467

in the Zagros basin, southeast-southwest Iran. Journal of Science of the Islamic Republic of Iran, v. 8, p. 243-261.

Guit, F.A, M.H. Al-Lawati and P.J.R. Nederlof 1995. Seeking new potential in the early-Late Permian Gharif play, west central Oman. In, M.I. Al-Husseini (Ed.), Middle East Petroleum Geosciences Conference, GEO'94. Gulf PetroLink, Bahrain, v. 2, p, 447462.

Hart, G.F. 1964. A review of the classification and distribution of the Permian miospore: Disaccate Striatiti. Cinqième Congrès International de Stratigraphie et de Géologie du Carbonifère, Paris 1963. Compte Rendu, v. 3, p. 1171-1199.

Hemer, D.O. 1965. Application of palynology in Saudi Arabia. Fifth Arab Petroleum Congress, Cairo, March 16th-23rd, 31 p.

Hudson, R.G.S. and M. Sudbury 1959. Permian brachiopoda from south east Asia. Notes et Memoires sur le Moyen-Orient, Museum National d'Histoire Naturelle, Paris v. 7, p. 19-55.

Hughes Clarke, M.W.H. 1988. Stratigraphy and rock unit nomenclature in the oil-producing area of Interior Oman. Journal of Petroleum Geology, v. 11, no. 1, p. 5-60.

Jizba, K.M.M. 1962. Late Palaeozoic bisaccate pollen from the United States midcontinent area. Journal of Paleontology, v. 36, p. 871-887.

Klaus, W. 1963. Sporen aus dem südalpinen Perm. Jahrbuch der Geologischen Bundesanstalt, Wien, v. 106, p. 229-363.

Lindström, S. 1996. Late Permian palynology of Fossilryggen, Vestfjella, Dronning Maud Land, Antarctica. Palynology, v. 20, p. 15-48. 
468

469

470

471

472

473

474

475

476

477

478

479

480

481

482

483

484

485

486

487

488

489

490

491

492

Loboziak, S. and G. Clayton 1988. The Carboniferous palynostratigraphy of northeast Libya. In, A. El-Arnauti, B. Owens and B. Thusu (Eds.), Subsurface Palynostratigraphy of Northeast Libya. Garyounis University Publications, Benghazi, Libya, p. 129-145.

Love, C.F. 1994. The palynostratigraphy of the Haushi Group (Westphalian-Artinskian) in Oman. In, M.D. Simmons (Ed.), Micropalaeontology and Hydrocarbon Exploration in the Middle East. Chapman and Hall, p. 23-39.

Luber, A.A. and I. E. Waltz 1941. Atlas of microspores and pollen grains of the Palaeozoic of the USSR. Trudy Vsesoiuznogo Nauchno-Issledovatel'skogo Geologicheskogo Instituta, Gosgeolizdat, Moscow/Leningrad, v. 139, p. 1-107. (In Russian).

MacRae, C.S. 1988. Palynostratigraphical correlation between the Lower Karoo sequence of the Waterburg and Pafuri coal basins and the Hammanskraal plant macrofossil locality, RSA. Memoirs of the Geological Survey of South Africa, v. 75, 217 p.

Marques-Toigo, M. 1974. Some new species of spores and pollens of Lower Permian age from the San Gregorio Formation in Uruguay. Anais da Academia Brasiliera de Ciêncas, v. 46, p. 601-616.

Miller, A.K. and W.M. Furnish 1957. Permian ammonoids from southern Arabia. Journal of Palaeontology, v. 31, p. 1043-1051.

Osterloff, P., A. Al-Harthy, R. Penney, P. Spaak, G. Williams, F. Al-Zadjali, N. Jones, R. Knox, M.H. Stephenson, G. Oliver and M.I. Al-Husseini 2004. Depositional sequence of the Gharif and Khuff formations, subsurface Interior Oman. In M.I. Al-Husseini (Editor), Carboniferous, Permian and Early Triassic Arabian Stratigraphy. GeoArabia Special Publication 3, Gulf PetroLink, Bahrain, p. 83-147.

Penney, R.A., I. Al Barram and M.H. Stephenson 2008. A high resolution palynozonation for the Al Khlata Formation (Pennsylvanian to Lower Permian), South Oman. Palynology, 32, 213-231. 
Platel, J.-P., J. Le Métour, A. Berthiaux, M. Beurrier and J. Roger 1992. Explanatory notes to the geologic map of the Juzor Al Halaaniyaat Quadrangle, Sultanate of Oman. Geoscience map, scale 1:250,000, sheet NE 40-10. Ministry of Petroleum and Minerals, Directorate General of Minerals, Sultanate of Oman. Muscat. 56 p.

Powis, G.D. 1979. Palynology of the Late Palaeozoic glacial sequence, Canning Basin, Western Australia. Unpublished Ph.D. thesis, University of Western Australia.

Punt, W., S. Blackmore, S. Nilsson and A. Le Thomas 1994. Glossary of pollen and spore terminology. LPP Foundation Contributions Series no. 1, 71 p.

Roger, J., S. Chevrel, J.-P. Platel, F. Bechennec, J. Dubreuilh, J. Le Metour and R. Wyns 1992. Geological map of Khaluf, sheet NF 40-15, scale 1:250,000 and explanatory notes: Directorate General of Minerals, Oman Ministry of Petroleum and Minerals. Muscat. 34 p.

Samoilovich, S.R. 1953. Pollen and spores from the Permian deposits of the Cherdya and Aktyubinsk areas, Cis-Urals. Oklahoma Geological Survey Circular 56, University of Oklahoma Press, p. 1-103. (originally in Russian, translated by Elias, M. K.).

Segroves, K.L. 1969. Saccate plant microfossils from the Perth Basin of Western Australia. Grana Palynologica, v. 9, p. 174-227.

Smith, A.H.V. and M.A. Butterworth 1967. Miospores in the coal seams of the Carboniferous of Great Britain. Special Papers of the Palaeontological Association, no. 1, p. 1-324.

Stephenson, M.H. 2004. Early Permian Spores from Oman and Saudi Arabia. GeoArabia Special Publication 3, Gulf PetroLink, Bahrain, p. 185-215.

Stephenson, M. H. 2008. Spores and Pollen from the Middle and Upper Gharif members (Permian) of Oman. Palynology, v. 32, p. 157-183.

Stephenson, M.H. and P.L. Osterloff 2002. Palynology of the deglaciation sequence represented by the Lower Permian Rahab and Lower Gharif members, Oman. 

41.

520 Stephenson, M.H., P.L. Osterloff and J. Filatoff 2003. Palynological biozonation of the Permian of Oman and Saudi Arabia: Progress and challenges. GeoArabia, v. 8, no. 3,

Stephenson, M.H., M.J. Leng, C.H. Vane, P.L. Osterloff and C. Arrowsmith 2005. Investigating the record of Permian climate change from argillaceous sediments, Oman. Journal of the Geological Society, London, v. 162, p. 641-651.

526 Tiwari, R.S. 1965. Miospore assemblage in some coals of the Barakar Stage (Lower 527 Gondwana) of India. Palaeobotanist, v. 13, p. 168-214.

528 Vergel, M. del M. 1987. Consideracions sobre el contenido microfloristico de al perforacion YPF SE AB (Palaeozoico Superior), Aabol Blanco, Provicia de Santiago del Estero, Argentina. VII Symposio Argentino de Paleobotanica y Palinologia, Actas. Buenos Aires, Abril, 1987, p. 75-76.

532 Wood, G.D., A.M. Gabriel and J.C. Lawson 1996. Chapter 3. Palynological techniques Processing and microscopy. In, J. Jansonius and D.C McGregor (Eds.), Palynology: Principles and Applications. American Association of Stratigraphic Palynologists Foundation, v. 1, p. 29-50. 


\section{Figure captions}

537

538 Fig. 1. Summary stratigraphy of the Carboniferous-Permian of Oman.

539 Fig. 2. Location of wells discussed in the text.

540 Fig. 3. Measurement and orientation scheme used for bisaccate pollen in this study, based on

541 Segroves (1969).

542 Fig. 4. Quantitative character of bisaccate pollen assemblages in Well A, Oman.

543 Fig. 5. The base of the OSPZ3a Sub-Biozone across the Rahab-2, Thuleilat-42 and 16, and

544 Marmul-151 wells (data from Stephenson and Osterloff, 2002).

545

546

\section{Plate captions}

548

549 Plate I. All figures with differential interference contrast (DIC) unless noted. Scale bar 550 indicates $10 \mu \mathrm{m}$.

551

552 1-18. Pteruchipollenites indarraensis.

553 1. R36, MPA 51778 showing variable form of the cappula.

$554 \quad 2 . \quad$ R36, MPA 51778 non-DIC.

$555 \quad$ 3. Q35, MPA 51778.

5564 433/4, MPA 51778 non-DIC.

557 5. R33/2, MPA 51778 non-DIC.

558 6. Q29/2, MPA 51778 non-DIC, slightly oblique compression.

559 7. Q29, MPA 51778 non-DIC.

560 8. Q28/2, MPA 51778 non-DIC. 
561 9. S29/1, MPA 51778 non-DIC, this specimen shows evidence of weak taeniae and may 562 be transitional to Protohaploxypinus limpidus.

563 10. N28/3, MPA 51778 lateral compression non-DIC.

564 11. N28/2, MPA 51778 lateral compression non-DIC.

565 12. N28/2, MPA 51778 showing dense cappa.

566 13. M29/3, MPA 51778 non-DIC.

567 14. M29/3, MPA 51778.

568 15. K16, MPA 51778 non-DIC.

569 16. P8/1, MPA 51778 non-DIC.

570 17. F21/2, MPA 51778 non-DIC.

$571 \quad$ 18. F21/2, MPA 51778.

572

573 Plate II. All figures with differential interference contrast (DIC) unless noted. Scale bar 574 indicates $10 \mu \mathrm{m}$.

575

576 1-10. Hamiapollenites fusiformis.

577 1. J21/3, MPA 51777 proximal focus.

$5782 . \quad$ J21/3, MPA 51777 focus on distal saccus roots.

579 3. Q16, MPA 51777 proximal focus.

580 4. Q16, MPA 51777 focus on distal saccus roots.

581 5. Q21/1, MPA 51784 proximal focus.

582 6. Q21/1, MPA 51784 focus on distal saccus roots.

583 7. N22, MPA 51774 proximal focus.

584 8. N22, MPA 51774 focus on distal saccus roots.

5859 9. P38, MPA 51795 non-DIC. 
10. P38, MPA 51795.

587

588 Plate III. All figures with differential interference contrast (DIC) unless noted. Scale bar 589 indicates $10 \mu \mathrm{m}$.

590

591 1-8. Striatopodocarpites cancellatus.

592 1. N27, MPA 51787 proximal focus.

5932 2. N27, MPA 51787 focus on saccus.

594 3. S16, MPA 51787 proximal focus.

595 4. S16, MPA 51787 focus on saccus.

596 5. S12, MPA 51770 non-DIC.

$597 \quad 6 . \quad$ S12, MPA 51770 focus on saccus.

598 7. M19/4, MPA 51790 proximal focus.

599 8. M19/4, MPA 51790 focus on distal saccus roots.

600

601 Plate IV. All figures with differential interference contrast (DIC) unless noted. Scale bar 602 indicates $10 \mu \mathrm{m}$.

603

604 1-3. Striatopodocarpites cancellatus.

605 1. H9/1, MPA 51779 proximal focus.

$606 \quad$ 2. H9/1, MPA 51779 focus on cappula.

607 3. H9/1, MPA 51779 focus on distal saccus roots.

608 4-5. Strotersporites indicus.

609 4. G35/2, MPA 51779.

$610 \quad$ 5. G35/2, MPA 51779. 
611 6-7. Strotersporites cf. indicus.

612 6. G35/1, MPA 51779 proximal focus.

613 7. K23, MPA 51779 focus on folds at distal saccus roots.

614 8. Protohaploxypinus amplus. F35/4, MPA 51779.

615 9. Protohaploxypinus limpidus. E27/4, MPA 51779. 


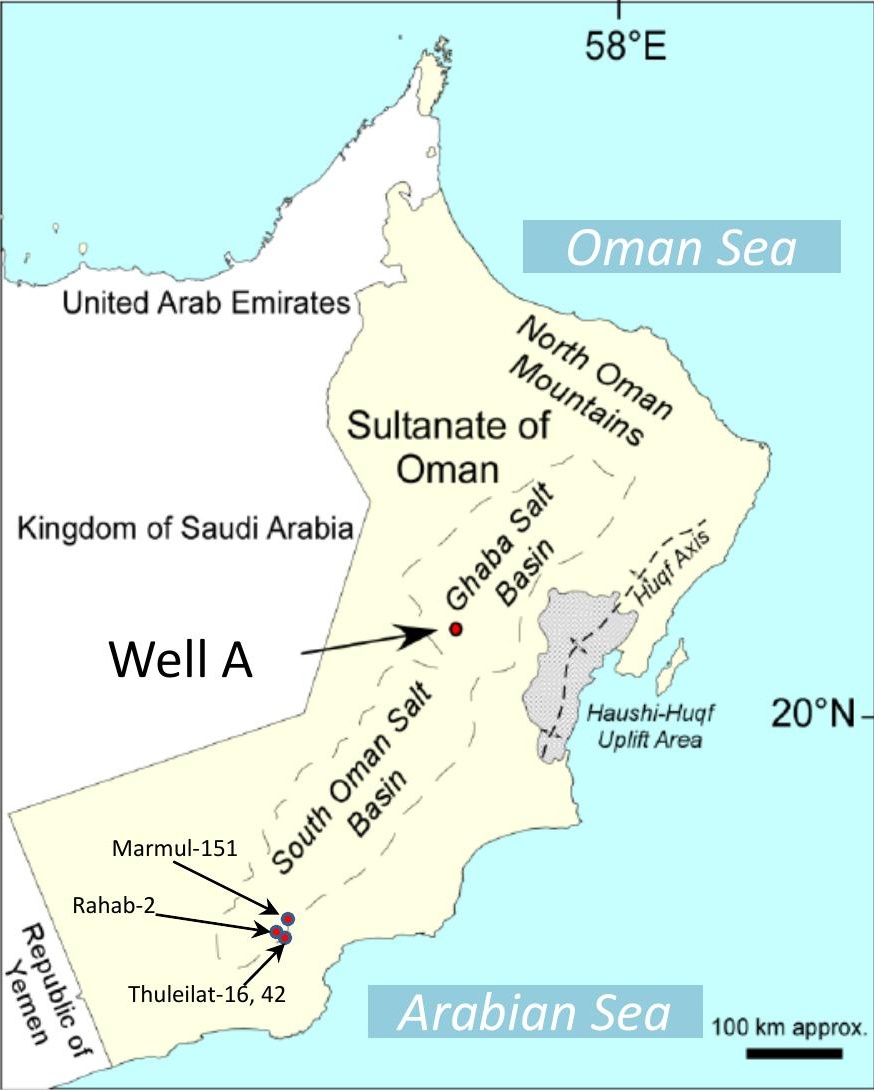


Diploxylonoid Bisaccate Grain

\section{Proximodistal view}

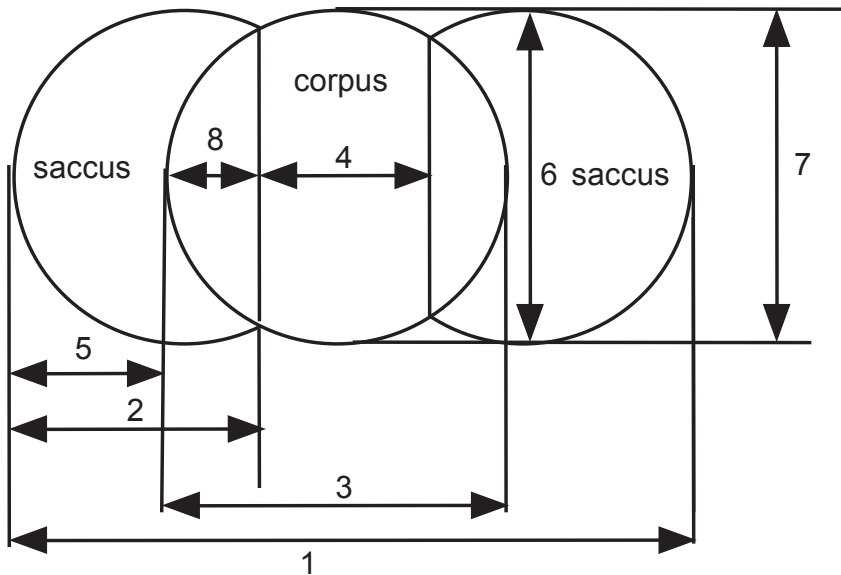

\section{Orientation}

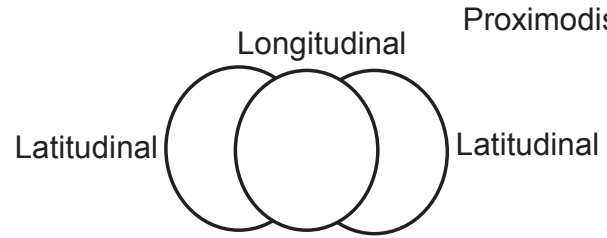

Longitudinal
Haploxylonoid Bisaccate Grain

Proximodistal view

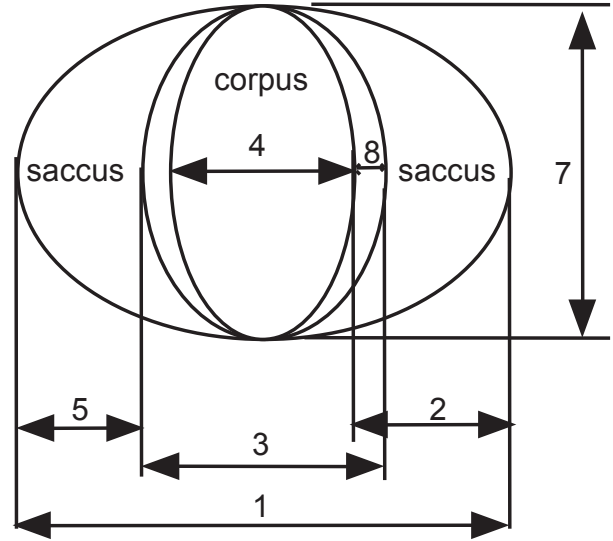

Key

1 Total Width

2 Saccus Width

3 Corpus Width

4 Cappula Width

5 Saccus Offlap

6 Saccus Length

7 Corpus Length

8 Saccus Onlap

\section{Saccus detachment}

$\mathrm{P}=$ proximal pole, $\mathrm{D}=$ distal pole

Asymmetrical saccus detachment: distal inclination

Symmetrical saccus detachment

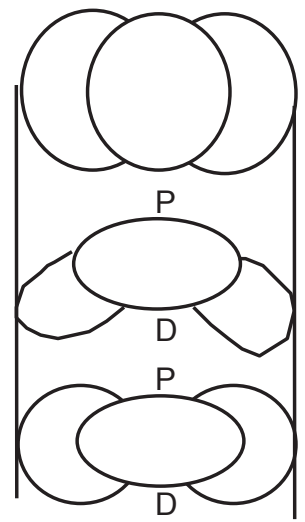

Proximodistal view

Cross section along latitudinal meridian 







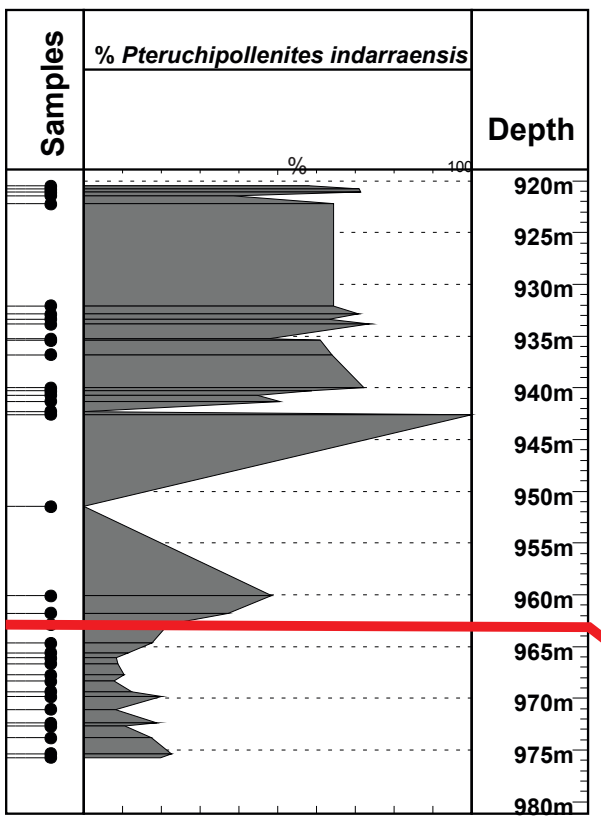

Base of the OSPZ3a Sub-Biozone

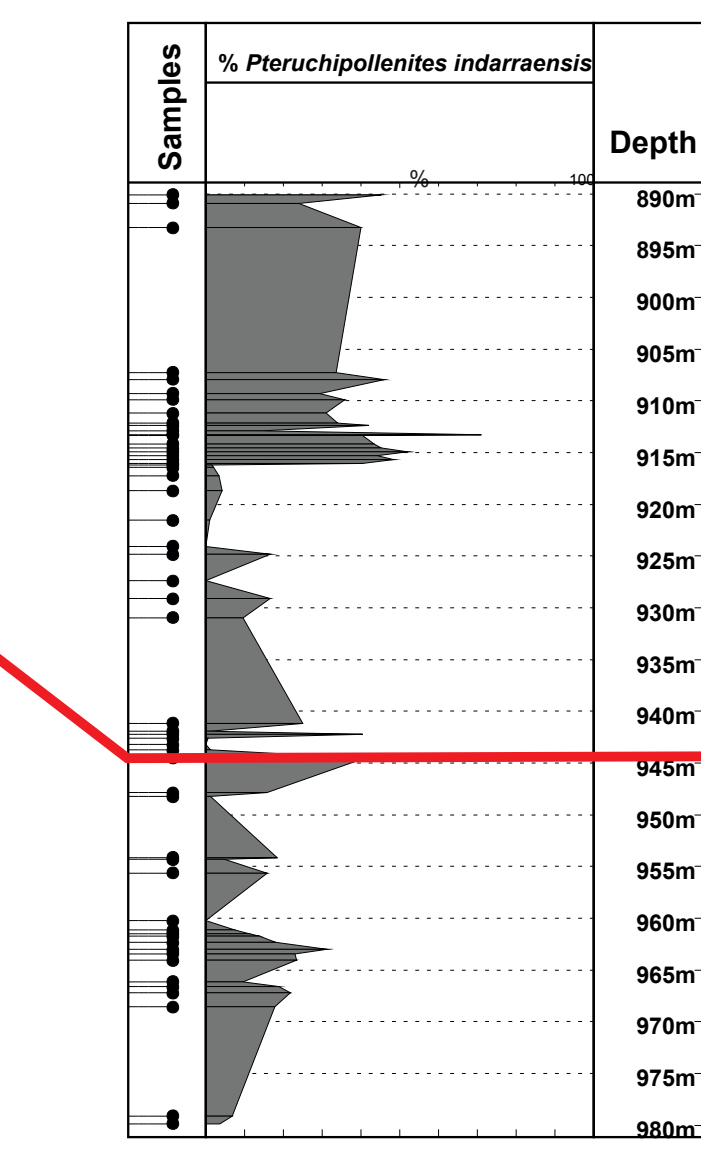

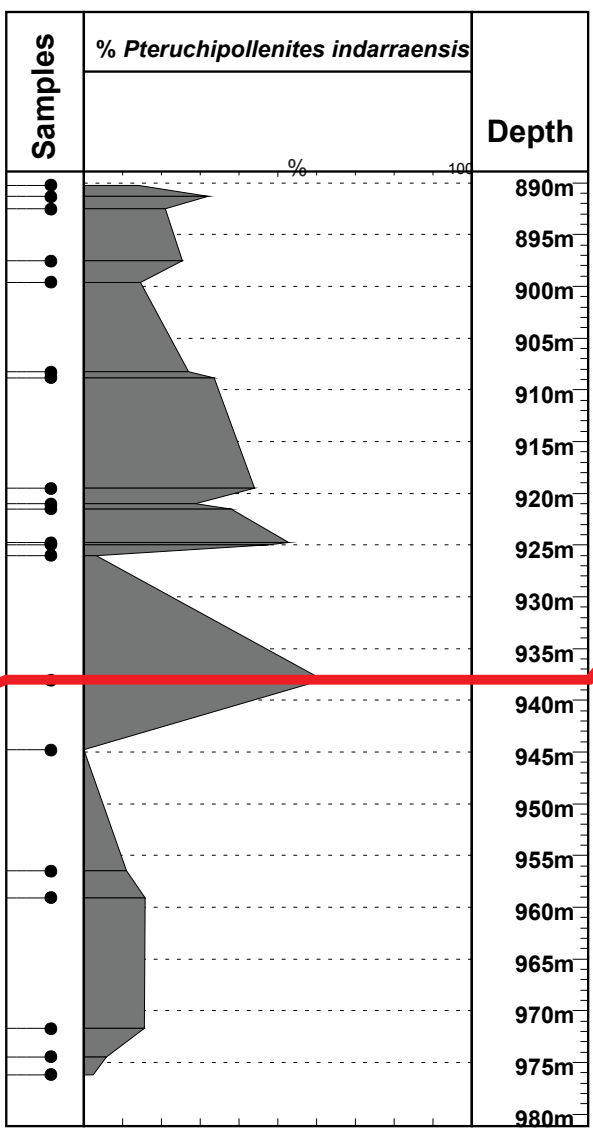

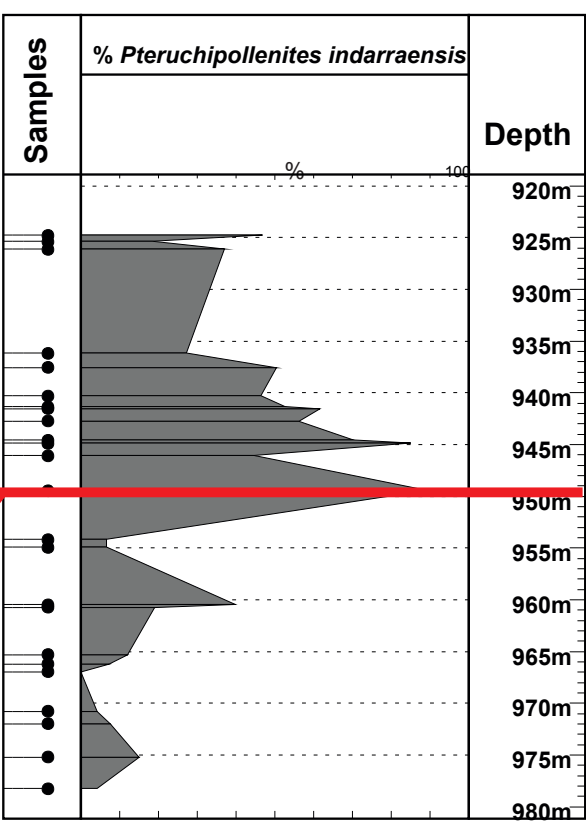




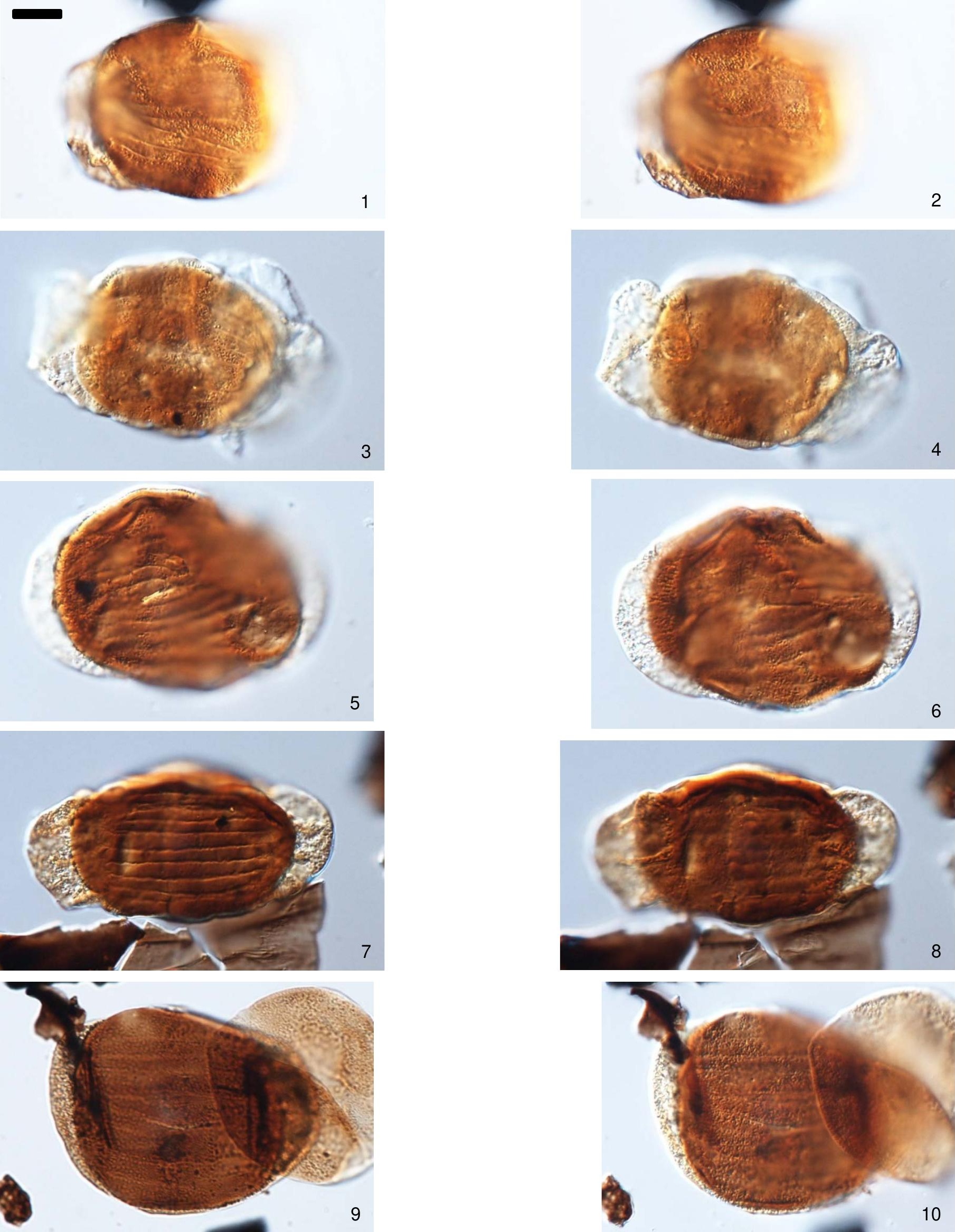


